\title{
STUDIES ON THE ANTI-OVULATORY AND OVULATORY ACTION OF CLOMIPHENE CITRATE IN THE RAT
}

\author{
F. DÖGKE \\ Institute of Experimental Endocrinology, Charité, \\ Humboldt University, Berlin, Germany
}

(Received 5th February 1970)

\begin{abstract}
Summary. To study the site and mechanism of its ovulation-inhibiting effect, clomiphene citrate was implanted bilaterally into the hypothalamus and hypophysis of adult di-oestrous rats and of prepuberal females which were also treated with oestradiol benzoate. The results suggest that this effect is primarily due to the action of clomiphene on the anterior pituitary. The anti-oestrogenic activity of clomiphene may prevent the action of oestrogen on the hypophysis, thus suppressing the increased gonadotrophin secretion leading to ovulation.

The ovulation-inducing effect of clomiphene was investigated in adult female rats which had been made anovulatory by destruction of the suprachiasmatic nuclei. Bilateral implantation of a small quantity of clomiphene citrate into the ventromedial-arcuate region resulted in corpus luteum formation and ovulation in these animals. A direct stimulation of the central hypothalamus is thought to be responsible for the ovulatory action of clomiphene in rats with cerebral lesions.
\end{abstract}

\section{INTRODUCTION}

In spite of the fact that clomiphene (1-[ $p$-( $\beta$-diethyl-aminoethoxy)-phenyl] 1,2-diphenyl-2-chloroethylene) is now widely used for the induction of ovulation in anovulatory women, the views on the mode of action of this substance are rather contradictory. Many authors assume a primary effect on the hypothalamo-hypophysial system (Greenblatt, 1961; Roy, Greenblatt, Mahesh \& Jungck, 1963; Thompson \& Mellinger, 1965; Wyss, Naville, Keller \& Gysel, 1966; Bardin, Ross \& Lipsett, 1967; Jacobson, Marshall \& Ross, 1968), but since the studies of Smith, Smith \& Kistner (1963) and Smith \& Day (1963), a direct effect on the ovary has also been under discussion (Breckwoldt \& Bettendorf, 1966; Hammerstein, 1967; Engels, Friedlander \& Eik-Nes, 1968). Investigations in laboratory animals have been complicated by the observation that the general effect of clomiphene in female rats is to inhibit ovulation. Recently, however, induction of ovulation was demonstrated in adult 
female rats that had been made anovulatory by postnatal androgenization, continuous light or selective lesions of the suprachiasmatic nuclei or the medial pre-optic area (Döcke, 1969). Based on these results, the sites of action and possible mechanisms of the ovulation-inhibiting and ovulation-inducing effects of clomiphene were studied in female rats.

\section{MATERIALS AND METHODS}

Juvenile and adult female Wistar rats were fed on a stock diet, housed in a temperature-controlled room and exposed to light from 05.00 to 19.00 hours. Vaginal smears were obtained from all mature animals at least 3 weeks before their experimental use, only rats with regular 4-day cycles being employed. For subcutaneous (s.c.) injections, each dose of clomiphene citrate and oestradiol benzoate (ODB) was dissolved in $0.2 \mathrm{ml}$ olive oil and $0.2 \mathrm{ml}$ sesame oil, respectively.

Intrahypothalamic and intrahypophysial implantation of clomiphene citrate was performed in the following way: the substance was dissolved in $70 \%$ ethanol, and a fixed quantity of the solution was aspirated into calibrated glass capillary tubes with an inner diameter of $0.2 \mathrm{~mm}$. After cleaning the outside of the capillaries, the alcohol was evaporated by warming the tubes in an incubator. Clomiphene recrystallized in the tip of the tube as a single plug. Prepuberal and adult female rats were anaesthetized with ether and fixed in a Horsley-Clarke stereotaxic instrument. Two capillaries, separated by $1 \mathrm{~mm}$, were introduced into the hypothalamus or the anterior pituitary and the clomiphene was expelled by means of a small agar plug and a stylette. The tubes were removed immediately after the deposition of the substance. Control implantations with cholesterol were performed in each experiment.

Bilateral lesions destroying the suprachiasmatic nuclei were produced in adult rats anaesthetized with ether by introducing two $0 \cdot 12-\mathrm{mm}$ platinum wires, glass-insulated to within $0.3 \mathrm{~mm}$ of their tips and with a space of $0.5 \mathrm{~mm}$ between them, into the medio-basal anterior hypothalamus. A current of $2 \mathrm{~mA}$ was applied for $8 \mathrm{sec}$.

The cyclic female rats were killed at noon on the day of expected oestrus and the animals with cerebral lesions on the 4th or 5th day after the injection or implantation of clomiphene. The tubes were opened under a dissecting microscope and the ova counted after the addition of hyaluronidase. Juvenile females were killed on the 6th day after the injection of ODB. Corpus luteum (CL) formation was studied in all prepuberal rats and in adult females in which tubal ova could not be found. Serial sections of the ovary, $5 \mu$ thick, were cut, every tenth section being mounted and stained with haematoxylin and eosin. The hypothalamus of each animal was fixed in $10 \%$ formalin, frozen, serially sectioned at $15 \mu$ and stained with haematoxylin and eosin. The pituitaries were fixed in sublimate: formol $(9: 1)$, embedded in paraffin, sectioned at $5 \mu$ and stained with haematoxylin and eosin.

The results were evaluated by the $\chi^{2}$-test using the correction formula of Yates. 


\section{RESULTS}

\section{Ovulation-inhibiting effect of clomiphene}

A single s.c. injection of clomiphene citrate was given to adult female rats weighing 180 to $220 \mathrm{~g}$ on the day of di-oestrus (i.e. the day before pro-oestrus) at 10.00 hours (Table 1, A). Spontaneous ovulation was prevented in seven out of eight females by the administration of $1 \mathrm{mg}$ clomiphene $/ \mathrm{kg}$ bodyweight and in four out of eight rats when $0.5 \mathrm{mg} / \mathrm{kg}$ were injected. Thus, $1 \mathrm{mg} / \mathrm{kg}$ was considered as the minimal ovulation-inhibiting dose.

TABLE 1

INHIBITION OF OVULATION AND GL FORMATION BY GLOMIPHENE IN ADULT AND PREPUBERAL RATS

\begin{tabular}{|c|c|c|c|c|}
\hline Group & Treatment & $\begin{array}{l}\text { No. of } \\
\text { rats }\end{array}$ & $\begin{array}{l}\text { Rats with } \\
\text { ovulation }(A) \\
\text { or } C L(B)\end{array}$ & $\begin{array}{l}\% \text { of the } \\
\text { treated rats }\end{array}$ \\
\hline \multirow[t]{3}{*}{ A. Adult females } & $\begin{array}{l}\text { Injection s.c. of } 3 \mathrm{mg} \text { clomiphene } / \mathrm{kg} \text { in } \\
\text { di-oestrus }\end{array}$ & 7 & 0 & - \\
\hline & $\begin{array}{l}\text { Injection s.c. of } 1 \mathrm{mg} \text { clomiphene } / \mathrm{kg} \text { in } \\
\text { di-oestrus }\end{array}$ & 8 & 1 & $12 \cdot 5$ \\
\hline & $\begin{array}{l}\text { Injection s.c. of } 0.5 \mathrm{mg} \text { clomiphene } / \mathrm{kg} \text { in } \\
\text { di-oestrus }\end{array}$ & 8 & 4 & $50 \cdot 0$ \\
\hline \multirow{4}{*}{$\begin{array}{l}\text { B. Prepuberal } \\
\text { females }\end{array}$} & Injection s.c. of $15 \mu \mathrm{g} \mathrm{ODB} *$ & 14 & 10 & $71 \cdot 4$ \\
\hline & $\begin{array}{l}\text { Injection s.c. of } 15 \mu \mathrm{g} \text { ODB and of } 2 \cdot 5 \\
\text { mg clomiphene/ } \mathrm{kg} \text { on the same and on } \\
\text { the following day }\end{array}$ & 16 & 2 & $12 \cdot 5$ \\
\hline & $\begin{array}{l}\text { Injection s.c. of } 15 \mu \mathrm{g} \text { ODB and of } 1.0 \\
\text { mg clomiphene/kg on the same and on } \\
\text { the following day }\end{array}$ & 16 & 3 & $18 \cdot 8$ \\
\hline & $\begin{array}{l}\text { Injection s.c. of } 15 \mu \mathrm{g} \text { ODB and of } 0.5 \\
\text { mg clomiphene/kg on the same and on } \\
\text { the following day }\end{array}$ & 14 & 8 & $57 \cdot 1$ \\
\hline
\end{tabular}

* $\mathrm{ODB}=$ oestradiol benzoate.

To examine the hypothesis that the ovulation-inhibiting effect of clomiphene in cyclic rats depends on the anti-oestrogenic properties of the substance, 26-day-old prepuberal female rats were injected s.c. with $15 \mu \mathrm{g}$ ODB and with different doses of clomiphene citrate on the same day and also on the following day. Table 1, B shows that the oestrogen-induced cL formation in most of the animals was prevented by the daily injection of at least $1 \mathrm{mg}$ clomiphene $/ \mathrm{kg}$. This result suggested that clomiphene inhibits ovulation in female rats by means of its anti-oestrogenic activity.

The possibility that a central action of clomiphene might be involved in this effect was tested in di-oestrous female rats by the bilateral intrahypothalamic or intrahypophysial implantation of $1 \mu \mathrm{g}$ clomiphene citrate, i.e. $1 / 100$ of the minimal s.c. effective dose (Table 2). Significant inhibition of spontaneous ovulation was only caused by implants located in the anterior pituitary.

As can be seen from Table 3 and Text-fig. 1, a similar result was obtained 
TABLE 2

EFFECT OF INTRAGEREBRAL IMPLANTS OF GLOMIPHENE ON OVULATION IN CYCLIC RATS

\begin{tabular}{|c|c|c|c|c|c|c|c|c|c|}
\hline \multirow{3}{*}{ Treatment } & \multicolumn{9}{|c|}{ Site of implantation } \\
\hline & \multicolumn{3}{|c|}{$\begin{array}{l}\text { Medial pre-optic-anterior } \\
\text { hypothalamic region }\end{array}$} & \multicolumn{3}{|c|}{$\begin{array}{l}\text { Ventromedial-arcuate } \\
\text { region }\end{array}$} & \multicolumn{3}{|c|}{ Anterior pituitary } \\
\hline & $\begin{array}{c}\text { No. of } \\
\text { rats }\end{array}$ & \begin{tabular}{|c} 
Rats $w$ \\
No.
\end{tabular} & $\begin{array}{c}\text { vulations } \\
\%\end{array}$ & $\begin{array}{c}\text { No. of } \\
\text { rats }\end{array}$ & $\begin{array}{l}\text { Rats w } \\
\text { No. }\end{array}$ & $\begin{array}{l}\text { vulations } \\
\%\end{array}$ & $\begin{array}{c}\text { No. of } \\
\text { rats }\end{array}$ & $\begin{array}{r}\text { Ratsw } \\
\text { No. }\end{array}$ & $\begin{array}{l}\text { ulations } \\
\%\end{array}$ \\
\hline $\begin{array}{l}\text { Bilateral implanta- } \\
\text { tion of } 1 \mu \mathrm{g} \text { clomi- } \\
\text { phene in di-oestrus }\end{array}$ & 14 & 9 & $64 \cdot 3$ & 19 & 6 & $31 \cdot 6$ & 17 & 4 & $23 \cdot 5^{*}$ \\
\hline $\begin{array}{l}\text { Bilateral implanta- } \\
\text { tion of } 1 \mu \mathrm{g} \text { choles- } \\
\text { terol in di-oestrus }\end{array}$ & 9 & 6 & $66 \cdot 7$ & 8 & 5 & $62 \cdot 5$ & 9 & 7 & $77 \cdot 8$ \\
\hline
\end{tabular}

* $P<0.05$, compared with the corresponding controls with cholesterol implants.

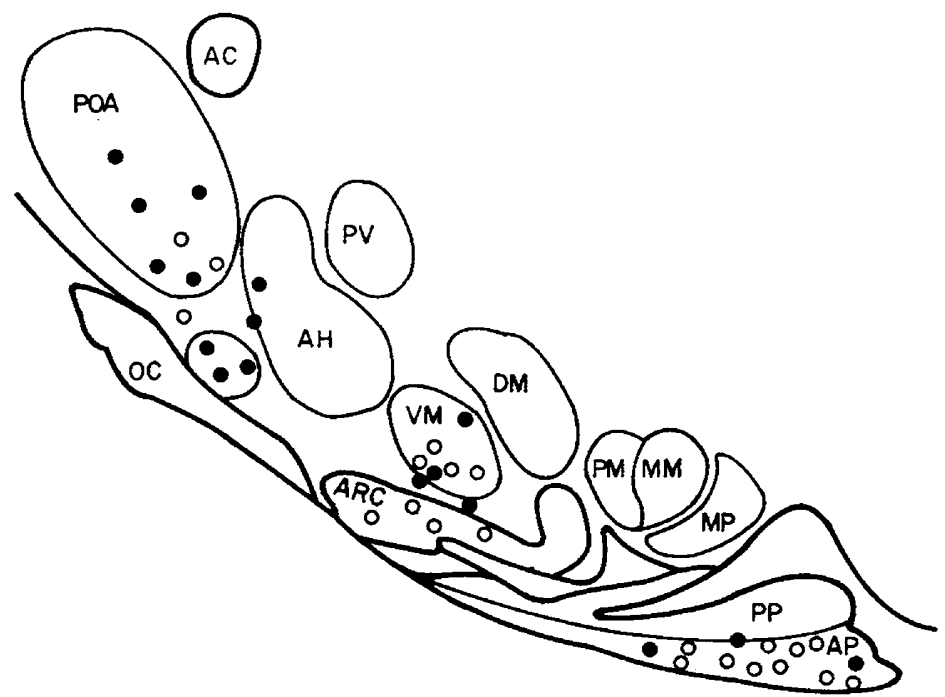

TexT-rig. 1. Parasagittal diagram of rat hypothalamus (de Groot, 1959) illustrating localizations of bilateral clomiphene implants in oestrogen-treated prepuberal female rats. Solid circles represent implants of rats that showed ct formation; open circles indicate implants of rats that did not exhibit cL formation. Abbreviations: $\mathrm{AC}=$ anterior commissure; $\mathrm{AH}=$ anterior hypothalamic area; $\mathrm{AP}=$ anterior pituitary; $\mathbf{A R C}=$ arcuate nucleus; $\mathrm{DM}=$ dorsomedial nucleus; $\mathrm{MM}=$ medial mammillary nucleus; MP = posterior mammillary nucleus; $O C=$ optic chiasma; $\mathbf{P M}=$ dorsal premammillary nucleus; $\mathbf{P O A}=$ pre-optic area; $\mathbf{P P}=$ posterior pituitary; $\mathrm{PV}=$ paraventricular nucleus; $\mathrm{SC}=$ suprachiasmatic nucleus; $\mathrm{VM}=$ ventromedial nucleus. 
in juvenile females that were injected s.c. with $15 \mu \mathrm{g}$ ODB and then implanted with $2 \mu \mathrm{g}$ clomiphene citrate in the medial pre-optic suprachiasmatic area, the ventromedial-arcuate region or the adenohypophysis. Again, the oestrogeninduced cL formation was most effectively prevented by implants situated in the adenohypophysis. As in adult females, a similar but somewhat weaker inhibition was observed after implantation of clomiphene into the ventromedialarcuate complex, whereas anterior hypothalamic implants were completely ineffective.

TABLE 3

EFFECT OF INTRACEREBRAL GLOMIPHENE IMPLANTS ON OESTROGEN-INDUCED GL FORMATION IN PREPUBERAL FEMALE RATS

\begin{tabular}{|c|c|c|c|c|c|c|c|c|c|}
\hline \multirow{3}{*}{ Treatment } & \multicolumn{9}{|c|}{ Site of implantation } \\
\hline & \multicolumn{3}{|c|}{$\begin{array}{l}\text { Medial pre-optic-anterior } \\
\text { hypothalamic region }\end{array}$} & \multicolumn{3}{|c|}{$\begin{array}{c}\text { Ventromedial-arcuate } \\
\text { region }\end{array}$} & \multicolumn{3}{|c|}{ Anterior pituitary } \\
\hline & $\begin{array}{c}\text { No. of } \\
\text { rats }\end{array}$ & $\begin{array}{l}\text { Rat: } \\
\text { No. }\end{array}$ & with $\underset{\%}{C L}$ & $\begin{array}{c}\text { No. of } \\
\text { rats }\end{array}$ & $\begin{array}{l}\text { Rats } \\
\text { No. }\end{array}$ & with $\underset{\%}{C L}$ & $\begin{array}{c}\text { No. of } \\
\text { rats }\end{array}$ & $\begin{array}{l}\text { Rats } \\
\text { No. }\end{array}$ & with $\underset{\%}{C L}$ \\
\hline $\begin{array}{l}15 \mu \mathrm{g} \text { ODB injected } \\
\text { s.c. }+1 \mu \mathrm{g} \text { clomiphene } \\
\text { implanted bilaterally }\end{array}$ & 13 & 10 & $75 \cdot 4$ & 12 & 4 & $33 \cdot 3$ & 13 & 3 & $23 \cdot 1^{*}$ \\
\hline $\begin{array}{l}15 \mu \mathrm{g} \text { ODB injected } \\
\text { s.c. }+1 \mu \mathrm{g} \text { cholesterol } \\
\text { implanted bilaterally }\end{array}$ & 9 & 6 & $66 \cdot 6$ & 10 & 7 & $70 \cdot 0$ & 10 & 8 & $80 \cdot 0$ \\
\hline
\end{tabular}

* $P<0.05$, compared with the corresponding controls with cholesterol implants.

TABLE 4

FAILURE OF GLOMIPHENE TO INDUCE GL FORMATION IN PREPUBERAL FEMALE RATS

\begin{tabular}{l|c|c|c}
\hline \multicolumn{1}{c|}{ Treatment } & No. of rats & Rats with CL & $\begin{array}{c}\% \text { of the } \\
\text { treated rats }\end{array}$ \\
\hline Injection s.c. of $15 \mu \mathrm{g}$ ODB & 81 & 56 & $69 \cdot 1$ \\
Injection s.c. of 0.2 to $20.0 \mathrm{mg}$ clomiphene $/ \mathrm{kg}$ & 186 & 10 & 5.4 \\
$\begin{array}{l}\text { Daily injection s.c. of } 0.03 \text { or } 0.1 \mathrm{mg} \text { clomi- } \\
\text { phene/kg for } 3 \text { days }\end{array}$ & 36 & 5 & 13.9 \\
\hline
\end{tabular}

\section{Ovulation-inducing effect of clomiphene}

Two experiments were performed to find out if clomiphene can induce ovulation on the basis of its oestrogenic activity. Twenty-six-day-old female rats were injected s.c. with different doses of clomiphene citrate and their controls with $15 \mu \mathrm{g}$ ODB. The data in Table 4 show that the effect of a single injection of ODB on CL formation could not be imitated by a single injection of 0.2 to $20.0 \mathrm{mg}$ clomiphene $/ \mathrm{kg}$ bodyweight. Since the best results had been obtained after the administration of $0 \cdot 1 \mathrm{mg}$ clomiphene $/ \mathrm{kg}$ (seven out of fifty-seven animals showed GL formation), distributed injections of this dose were given 
additionally. Again, only $13.7 \%$ of the rats exhibited cL formation compared with $69.1 \%$ after the administration of ODB.

Everett (1948) has shown that, in cyclic female rats, the ovulation-delaying effect of an injection of progesterone in metoestrus can be abolished by the administration of oestrogen 1 day later. This advancement of ovulation was not obtained when clomiphene was given instead of oestrogen (Table 5).

\section{TABLE 5}

EFFECT OF GLOMIPHENE ON OVULATION IN PROGESTERONE-TREATED GYGLIC RATS

\begin{tabular}{l|c|c|c}
\hline \multicolumn{1}{c|}{ Treatment } & No. of rats & $\begin{array}{c}\text { Rats with } \\
\text { ovulations }\end{array}$ & Eggs/rat \\
\hline $\begin{array}{l}\text { Injection s.c. of } 1.5 \mathrm{mg} \text { progesterone in metoestrus } \\
\text { Injections s.c. of } 1.5 \mathrm{mg} \text { progesterone in met- } \\
\text { oestrus and of } 25,50 \mathrm{or} 100 \mu \mathrm{g} \text { ODB in di-oestrus }\end{array}$ & 10 & 1 & 7.0 \\
$\begin{array}{l}\text { Injections s.c. of } 1.5 \mathrm{mg} \text { progesterone in met- } \\
\text { oestrus and of } 5,15 \mathrm{or} 25 \mathrm{mg} \text { clomiphene } / \mathrm{kg} \text { in } \\
\text { di-oestrus }\end{array}$ & 22 & 1 & 2.0 \\
$\begin{array}{l}\text { Injections s.c. of } 1.5 \mathrm{mg} \text { progesterone in met- } \\
\text { oestrus and of } 5 \text { or } 25 \mathrm{mg} \text { clomiphene/kg in met- } \\
\text { oestrus, di-oestrus and pro-oestrus }\end{array}$ & 11 & 0 & - \\
\hline
\end{tabular}

TABLE 6

OVULATORY REAGTION OF ADULT RATS WITH BRAIN LESIONS TO THE INTRAGEREBRAL IMPLANTATION OF GLOMIPHENE

\begin{tabular}{|c|c|c|c|c|c|c|c|c|c|}
\hline \multirow{3}{*}{ Treatment } & \multicolumn{9}{|c|}{ Site of implantation } \\
\hline & \multicolumn{3}{|c|}{ Medial pre-optic area } & \multicolumn{3}{|c|}{$\begin{array}{l}\text { Ventromedial-arcuate } \\
\text { complex }\end{array}$} & \multicolumn{3}{|c|}{ Anterior pituitary } \\
\hline & $\begin{array}{c}\text { No. of } \\
\text { rats }\end{array}$ & $\begin{array}{l}\text { Rats } \\
\text { No. }\end{array}$ & with $\begin{array}{c}C L \\
\%\end{array}$ & $\begin{array}{l}\text { No. of } \\
\text { rats }\end{array}$ & $\begin{array}{l}\text { Rats } \\
\text { No. }\end{array}$ & with $C L$ & $\begin{array}{c}\text { No. of } \\
\text { rats }\end{array}$ & $\begin{array}{l}\text { Rats with } \\
\text { No. }\end{array}$ & $C L$ \\
\hline $\begin{array}{l}\text { Bilateral implanta- } \\
\text { tion of } 3 \mu \mathrm{g} \text { clomi- } \\
\text { phene }\end{array}$ & 12 & 2 & $16 \cdot 7$ & 12 & 10 & $83 \cdot 3$ & 10 & 0 & - \\
\hline $\begin{array}{l}\text { Bilateral implanta- } \\
\text { tion of } 3 \mu \mathrm{g} \text { choles- } \\
\text { terol }\end{array}$ & 7 & 1 & $14 \cdot 3$ & 8 & 1 & $12 \cdot 5$ & 7 & 0 & - \\
\hline
\end{tabular}

* $P<0.01$, compared with the corresponding controls with cholesterol implants.

On the other hand, clomiphene can induce ovulation in adult female rats with anterior hypothalamic lesions of the gonadotrophin-controlling centre (Döcke, 1969). To investigate the site of clomiphene action in this effect, bilateral lesions destroying the suprachiasmatic nuclei only were produced in cyclic female rats weighing 150 to $180 \mathrm{~g}$ and exhibiting regular 4-day ovarian cycles (Pl. 1, Fig. 1). Persistent vaginal cornification resulted from this treatment in most of the animals. After at least 3 weeks of permanent vaginal oestrus, laparotomy was carried out to establish the absence of GL. Fifteen rats 


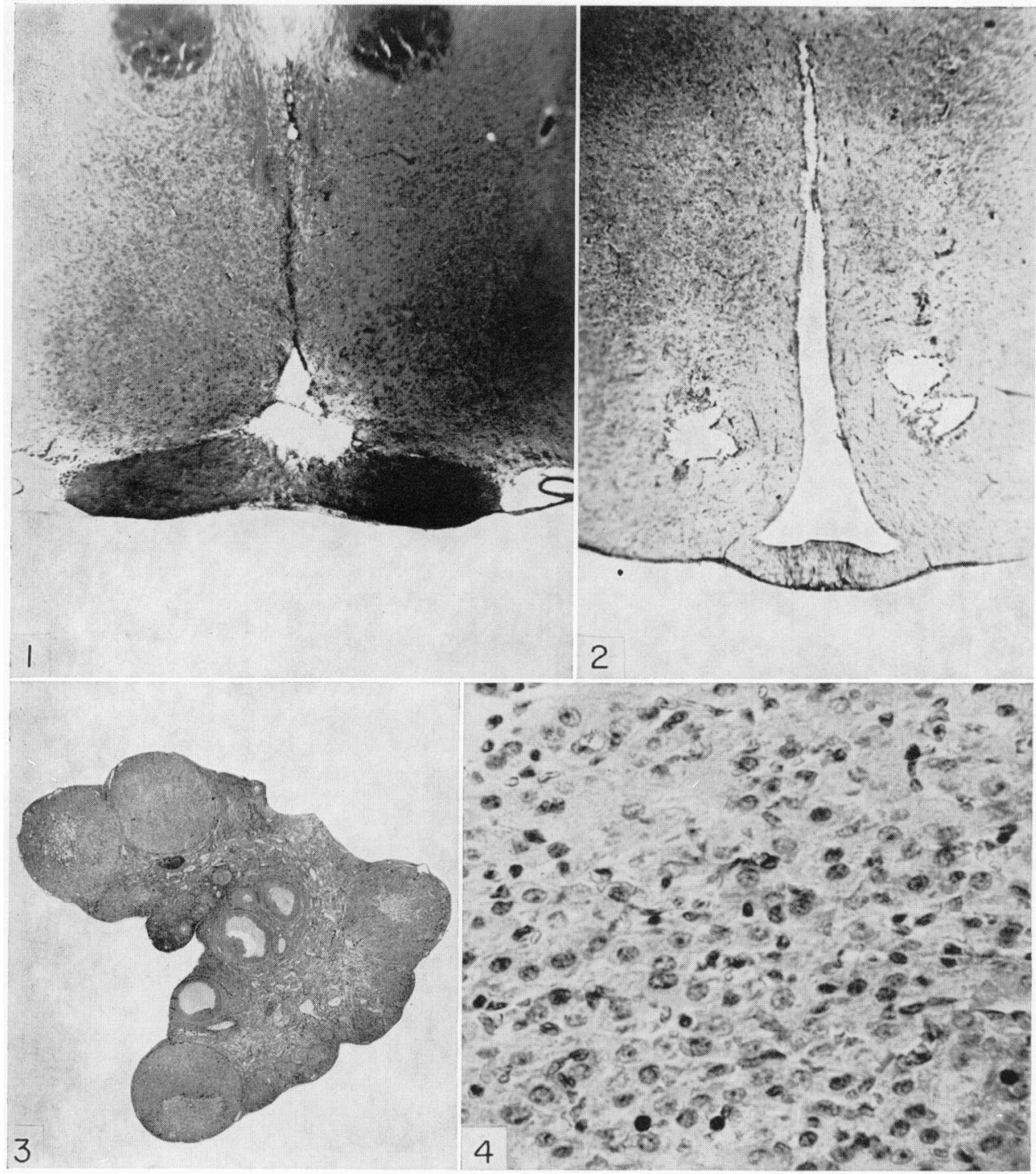

FIG. 1. Anterior hypothalamic lesion involving the main parts of the suprachiasmatic nuclei of an adult female rat. Anovulation and permanent vaginal oestrus resulted from this lesion. $\times 17$.

FIG. 2. Clomiphene implants marked by agar plugs in the ventromedial-arcuate region of an anovulatory rat with brain lesions. Ovulation was induced by these implants. $\times 17$.

FIG. 3. Ovary of an adult rat with brain lesions which exhibited ci. formation after the implantation of clomiphene. Ovulated eggs could not be found in this animal, $\times 9$.

FIG. 4. Portion of a cL in Fig. 3 showing the normal appearance of luteal tissue. $\times 266$. 
without CL received a single s.c. injection of 10,5 or $3 \mathrm{mg}$ clomiphene $/ \mathrm{kg}$ bodyweight. Twelve animals showed CL formation at autopsy on the 4th or 5th day after this treatment, whereas cL could not be found in six rats that had been injected with $1 \mathrm{mg}$ clomiphene $/ \mathrm{kg}$. These results show that a single injection of clomiphene is sufficient for the induction of GL formation in permanently oestrous rats and that the minimal dose for this effect is $3 \mathrm{mg} / \mathrm{kg}$ in the Wistar strain used.

Bilateral intrahypothalamic or intrahypophysial implantations of $1 / 100$ of this clomiphene dose (Pl. 1, Fig. 2) were then performed in rats in persistent oestrus with cerebral lesions, which did not show cL at laparotomy. Table 6 and Text-fig. 2 demonstrate that $\mathrm{CL}$ formation was only induced by implants localized in the ventromedial-arcuate region (Pl. 1, Figs. 2, 3, 4), but not by implants placed in the medial pre-optic area or the adenohypophysis.

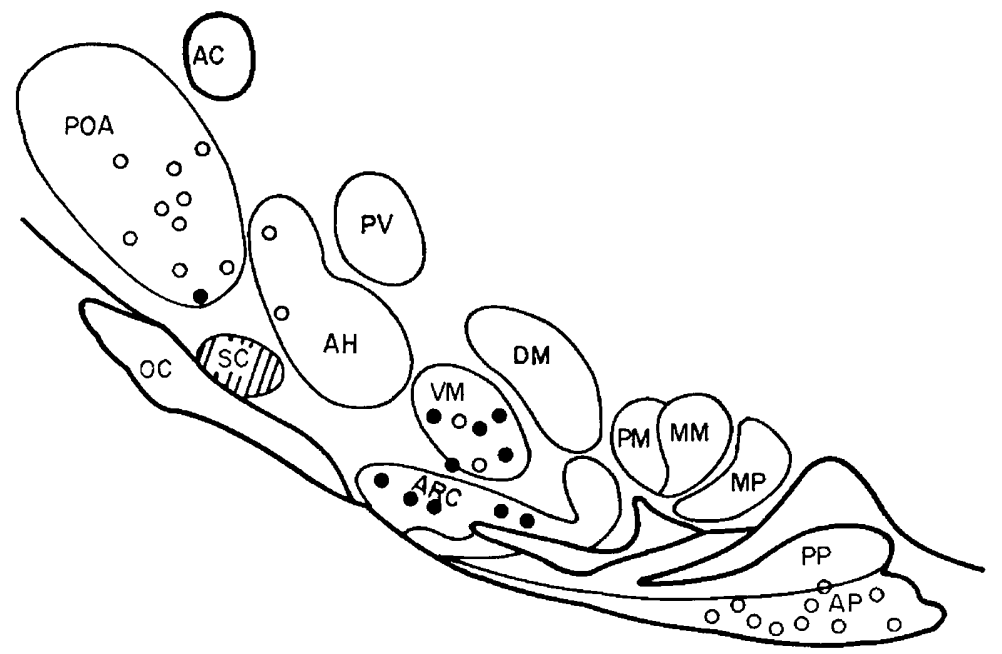

TEXT-FIg. 2. Parasagittal diagram of rat hypothalamus demonstrating localizations of bilateral clomiphene implants in adult rats in persistent oestrus. Solid circles $=$ implants of rats that showed cL formation; open circles = implants of rats that did not exhibit CL formation. For abbreviations see Text-fig. 1.

After autopsy, the hypothalamus of each rat was examined histologically. Only animals in which selective destruction of the suprachiasmatic nuclei could be established were included in the evaluation. The tubes and uteri were flushed with saline in all rats that showed cL formation at autopsy. Ova could be found in only five injected and four implanted females.

\section{DISCUSSION}

A strong anti-oestrogenic activity of clomiphene citrate has been established in many experiments (Van Maanen, Greslin, Holtkamp \& King, 1961; Roy, Greenblatt \& Mahesh, 1964). The first part of the present study suggests that this anti-oestrogenic potency is responsible for the prevention of CL formation by clomiphene in juvenile rats treated with ODB. Since an increase of oestrogen 
secretion is also indispensable for ovulation in cyclic female rats (Schwartz, 1964), clomiphene-induced inhibition of ovulation in these animals may be based on the same mechanism. The results also indicate that the anterior pituitary is the primary site of clomiphene action in these effects. They are in good agreement with the findings of Kato, Kobayashi \& Villee (1968), who demonstrated that the administration of clomiphene causes a marked, dosedependent depression in the uptake of tritiated oestradiol by the anterior pituitary in adult ovariectomized rats. In their experiments, the minimal effective clomiphene dose for a single injection was $1 \mathrm{mg} / \mathrm{kg}$ bodyweight, exactly the minimal quantity that suppressed spontaneous ovulation in the present study. As was shown by Roy, Mahesh \& Greenblatt (1964), clomiphene prevents the entry of oestrogen into, and may even displace it from, the anterior pituitary in immature female rats.

The present findings support the view that the hypophysis is the main site of action of oestrogen in its ovulation-inducing capacity in rats (Döcke \& Dörner, 1965). If oestrogens act primarily on the hypothalamus in this positive feedback, clomiphene implants placed in the medial pre-optic suprachiasmatic region or in the ventromedial-arcuate complex would be expected to prevent CL formation in oestrogen-treated prepuberal rats and ovulation in cyclic females. However, significant inhibition of both processes was only seen after intrahypophysial implantation of this substance. The somewhat weaker but nevertheless distinct effect of implants located in the ventromedial-arcuate region may be explained by the transport of clomiphene to the anterior pituitary through the portal vessels (Bogdanove, 1963). By contrast, substances acting on the hypothalamus are inefficient after intrahypophysial implantation (Döcke \& Dörner, 1969).

According to the hypothesis of Döcke \& Dörner (1965) concerning the action of oestrogen in ovulation, clomiphene may prevent the oestrogeninduced sensitization of the anterior pituitary to the hypothalamic gonadotrophin-releasing factors, and so suppress the ovulation-inducing gonadotrophin secretion. Gestagens may have a similar effect. It was shown by Döcke, Dörner \& Voigt (1968), and most recently established by Spies, Stevens, Hilliard \& Sawyer (1969), that these hormones also inhibit ovulation by their action on the adenohypophysis.

The present evidence for the hypothalamus as the site of the ovulationinducing action of clomiphene supports the similar conclusion drawn by Igarashi, Ibuki, Kubo, Kamioka, Yokota, Ebara \& Matsumoto (1967) and Schneider, Staemmler, Straehler-Pohl \& Sachs (1968) from their studies in intact prepuberal and adult female rats and in ovariectomized females, respectively. It is also in agreement with the results of Baier \& Taubert (1969), who found a significant decrease of hypothalamic FSH-releasing factor content after the administration of clomiphene to ovariectomized, oestrogen-progesterone-blocked female rats.

The mechanism of this effect cannot conclusively be derived from the present results, since both the suppression of the negative oestrogen feed-back (Lisk, 1960; Kanematsu \& Sawyer, 1964), supposed by Wyss et al. (1966) and Roy et al. (1963) to be responsible for the action of clomiphene in women, and a 
direct hypothalamic stimulation, might be effective in the ventromedialarcuate region. However, Schneider et al. (1968) found an increased LH secretion in ovariectomized adult rats after the administration of clomiphene. The result strongly suggests that, in this animal, the prevention of the negative oestrogen feed-back is not necessarily involved in the stimulation of gonadotrophin secretion by clomiphene. This may also apply to women since induction of ovulation after clomiphene therapy was seen by Roy et al. (1963) in two patients with Chiari-Frommel syndrome and by Wider, Neuwirth \& van de Wiele (1968) in fourteen out of twenty female patients with polycystic ovaries that had not ovulated after wedge resection.

Clomiphene can also induce ovulation in pseudopregnant female rats (Watnick \& Neri, 1968; Taubert, Schwantje \& May, 1969), an effect which was thought to depend on the oestrogenic activity of the substance (Watnick \& Neri, 1968). However, the present results and the observation (not published) that a single s.c. or i.v. injection of $100 \mu \mathrm{g}$ ODB induced cL formation in only one out of ten adult rats in which the suprachiasmatic nuclei had been destroyed do not support this assumption. Thus, the conclusion may be drawn that a direct stimulation of the central hypothalamus is responsible for the induction of ovulation by clomiphene in adult rats with cerebral lesions.

The fact that ova could not be found in the tubes or uteri of many adult females which had reacted to the administration of clomiphene by cL formation cannot be explained at present. Most of the serially sectioned $\mathrm{CL}$ in rats without established ovulation did not contain ova and had a similar histological structure to those of cyclic females 2 to 4 days after ovulation. They differed clearly from the thecal CL with entrapped ova described by Harris (1964). Since CL formation was induced in polycystic ovaries, it is possible that the eggs may have degenerated or that their transport through the genital tract was accelerated.

\section{REFERENCES}

BAIER, H. \& TAUBERT, H.-D. (1969) Effect of clomiphene upon plasma FSH-activity and hypothalamic FSH-RF content in ovariectomized estrogen-progesterone blocked rats. Endocrinology, 84, 946.

Bardin, G. W., Ross, G. T. \& Lipsett, M. B. (1967) Site of action of clomiphene citrate in men: a study of the pituitary-Leydig cell axis. F. clin. Endocr. Metab. 27, 1558.

Bogdanove, E. M. (1963) Direct gonad-pituitary feedback: an analysis of effects of intracranial estrogenic depots on gonadotrophin secretion. Endocrinology, 73, 696.

BRECKWOLdT, M. \& Bettendorf, G. (1966) Einfluss von Clomiphen auf die Gonadotropinwirkung im biologischen Test. Arch. Gynaek. 203, 491.

Döcke, F. (1969) Ovulation-inducing action of clomiphene in the rat. F. Reprod. Fert. 18, 135.

Döcke, F. \& Dörner, G. (1965) The mechanism of the induction of ovulation by oestrogens. $\mathcal{F}$. Endocr. 33, 491.

DöCKe, F. \& DöRNER, G. (1969) A possible mechanism by which progesterone facilitates ovulation in the rat. Neuroendocrinology, 4, 139.

Döcke, F., Dörner, G. \& Voigt, K.-H. (1968) A possible mechanism of the ovulation-inhibiting effect of chlormadinone acetate in the rat. F. Endocr. 41, 353.

Engels, J. A., Friedlander, R. L. \& Eik-Nes, K. B. (1968) An effect in vivo of clomiphene on the rate of conversion of androstenedione- $\mathrm{C}^{14}$ to estrone- $\mathrm{C}^{14}$ and estradiol- $\mathrm{C}^{14}$ by the canine ovary. Metabolism, 17, 189.

Everetr, J. W. (1948) Progesterone and estrogen in the experimental control of ovulation time and other features of the estrous cycle in the rat. Endocrinology, 43, 389.

Greenblatr, R. B. (1961) Chemical induction of ovulation. Fert. Steril. 12, 402.

Groot, J. DE (1959) The rat forebrain in stereotaxic coordinates. Verh. K. ned. Akad. Wet. Series 2, 52, 1. 
Hammerstein, J. (1967) Action of clomiphene citrate on the in vitro biosynthesis of steroids in slices of human corpora lutea. Atta endocr., Copenh. Suppl. 119, 79.

HARRIs, G. W. (1964) Sex hormones, brain development and brain function. Endocrinology, 75, 627.

Igarashi, M., Ibuki, Y., Kubo, H., Kamioka, J., Yokota, N., Ebara, Y. \& Matsumoto, S. (1967) Mode and site of action of clomiphene. Am. 7. Obstet. Gynec. 97, 120.

Jacobson, A., Marshall, J. R. \& Ross, G. T. (1968) Plasma luteinizing hormone during clomipheneinduced ovulatory cycles. Am. 7. Obstet. Gynec. 101, 1025.

KANEMATSU, S. \& SAWYER, C. H. (1964) Effects of hypothalamic and hypophysial estrogen implants on pituitary and plasma LH in ovariectomized rabbits. Endocrinology, 75, 579.

Kato, J., Kobayashi, T. \& VilleE, C. A. (1968) Effect of clomiphene on the uptake of estradiol by the anterior hypothalamus and hypophysis. Endocrinology, 82, 1049.

Lisk, R. D. (1960) Estrogen-sensitive centers in the hypothalamus of the rat. F. exp. Zool. 145, 197.

Roy, S., GReenblatt, R. B. \& Mahesh, V. B. (1964) Effects of clomiphene on the physiology of reproduction in the rat. II. Its oestrogenic and antioestrogenic actions. Acta endocr., Copenh. 47, 657.

Roy, S., Greenblatt, R. B., Mahesh, V. B. \& Jungck, E. G. (1963) Clomiphene citrate: further observations on its use in induction of ovulation in the human and on its mode of action. Fert. Steril. 14, 575.

Roy, S., Mahesh, V. B. \& Greenblatt, R. B. (1964) Effects of clomiphene on the physiology of reproduction in the rat. III. Inhibition of uptake of radioactive oestradiol by the uterus and the pituitary gland of immature rat. Acta endocr., Copenh. 47, 669.

Schnemer, H. P. G., Staemmler, H.-J., Straehler-Pohl, K. \& Sachs, L. (1968) Hypothalamische LH-Freigabe-Funktion und Clomiphen. Acta endocr., Copenh. 58, 347.

Schwartz, N. B. (1964) Acute effects of ovariectomy on pituitary LH, uterine weight, and vaginal cornification. Am. 7. Physiol. 207, 1251.

Smith, O. W. \& DAy, G. F. (1963) Effect of clomiphene on aromatization of steroids by the human placenta in vitro. Acta endocr., Copenh. 44, 519.

Sмith, O. W., Sмith, G. V. \& Kistner, R. W. (1963) Action of MER-25 and of clomiphene on the human ovary. 7. Am. med. Ass. 184, 878.

Spies, H. G., Stevens, K. R., Hilliard, J. \& Sawyer, G. H. (1969) The pituitary as a site of progesterone and chlormadinone blockade of ovulation in the rabbit. Endocrinology, 84, 277.

Taubert, H.-D., Schwantje, R. \& May, E. (1969) Induction of ovulation with clomiphene and related agents in the pseudopregnant rat. Acta endocr., Copenh. Suppl. 138, 202.

Thompson, R. J. \& Mellinger, R. C. (1965) The effects of clomiphene citrate in patients with pituitary-gonadal disorders. Am. 7. Obstet. Gynec. 92, 412.

Van Maanen, E. F., Greslin, J. G., Holtkamp, D. E. \& King, W. M. (1961) Endocrine and other biological effects of chloramiphene. Fedn Proc. Fedn Am. Socs exp. Biol. 20, 419.

WAtNICK, A. S. \& NERI, R. O. (1968) Biological properties of three ovulation inducers, stilboestrol, clomiphene and F 6066. Acta endocr., Copenh. 59, 611.

Wider, J. A., NeUwirth, R. S. \& VAN DE Wiele, R. L. (1968) Use of clomiphene citrate in treatment of wedge resection failures and as a preoperative test for wedge resection success. Am. 7. Obstet. Gynec. 101, 740.

Wyss, H. J., Naville, A. H., Keller, P. J. \& Gysel, J. (1966) Clomid, ein neues ovulationsauslösendes Medikament. Schweiz. med. Wschr. 96, 1529. 